\title{
LITERACKIE TOPOGRAFIE POGRANICZA. PRZYPADEK SLAWONII
}

\author{
MAGDALENA DYRAS 1 \\ (Kraków)
}

Słowa kluczowe: regionalizm, Slawonia, pogranicza, nostalgia, pamięć, interakcja kulturowa

Keywords: regionalism, Slavonia, borderlands, nostalgia, memory, cultural interaction

\begin{abstract}
Abstrakt: Magdalena Dyras, LITERACKIE TOPOGRAFIE POGRANICZA. PRZYPADEK SLAWONII. „PORÓWNANIA” 11, 2012, Vol. XI, ss. 157-165, ISSN 1733-165X. W ostatnich latach w Chorwacji ożywa duch regionalizmu, który można by nazwać „nowym regionalizmem” w odróżnieniu od tendencji, jakie przez wieki kształtowały oblicze kultury chorwackiej. Można również określić nową sytuację mianem "decentralizacji mapy”, wyrażającą się w zainteresowaniu obszarami granicznymi, peryferiami. Slawonia, przestrzeń przecięcia się i spotkania różnych kultur, również przeżywa znaczące przemiany. W prozie chorwackiej pojawiają się próby odtworzenia środkowoeuropejskiego ducha regionu poprzez odkrywanie śladów przeszłości, za sprawą swego rodzaju literackiej archeologii zmierzającej do odnalezienia, mówiąc słowami Aleidy Assmann „śladów, reliktów, bruzd i ran” określających dane miejsca. Interesującym przypadkiem takiego poszukiwania jest proza autorów pochodzenia niemieckiego, szczególnie Ludwiga Bauera, autora powieści wskrzeszających ducha pogranicza.
\end{abstract}

Abstract: Magdalena Dyras, LITERARY TOPOGRAPHY OF THE BORDERLAND. THE CASE OF SLAVONIA. "PORÓWNANIA" 11, 2012, Vol. XI, pp. 157-165, ISSN 1733-165X. The regionalist spirit has been revived during recent years in Croatia. The spirit can be called "new regionalism" as opposed to the tendencies which shaped the Croatian culture for centuries. The new situation can also be referred to as "map decentralization" which is visible in the interest in fringe areas and peripheries. Slavonia, the area of intersection and meeting of different cultures, is also undergoing significant changes. In the Croatian prose there are attempts at recreating the Central European spirit of the region by means of finding traces of the past due to a kind of literary archeology which aims at finding what Aleida Assmann would call "traces, relicts, furrows and wounds" which characterize the particular places. An interesting case of such searching is the prose of authors of German origin, particularly Ludwig Bauer who is the author of a novel which revives the spirit of the borderland.

\footnotetext{
${ }^{1}$ Correspondence Address: dyraf@o2.pl
} 
Slawonia to region Chorwacji naznaczony pogranicznością, przestrzeń, w której od dawien dawna krzyżowały się różne wpływy, miejsce spotkań wielu kultur i języków. Po drugiej wojnie światowej i utworzeniu federacyjnego państwa Jugosławii, usuwanie śladów wielowiekowych interakcji, wymazywanie pamięci o mniejszościach narodowych, które wywierały ogromny wpływ na oblicze regio$\mathrm{nu}$, stanowiło element polityki nowych władz. Za wszelką cenę dążono do urzeczywistnienia hasła „braterstwa i jedności” poszczególnych narodów współtworzących federację, wykluczając i stygmatyzując "obcych". Szczególnie dotyczyło to mniejszości niemieckiej, obarczanej winą za tragedię wojny, niezależnie od rzeczywistego zaangażowania po stronie okupanta. Działania podejmowane po roku 1945, represje, rekwizycja mienia, spowodowały zmianę oblicza regionu oraz doprowadziły do wyeliminowania niepożądanych grup ludności. Dopiero po rozpadzie Jugosławii, kiedy nowopowstałe państwo chorwackie elementem swojej polityki uczyniło podkreślanie więzi z „cywilizowaną Europą”, dopuszczono do głosu przedstawicieli mniejszości narodowych i przywrócono im ich prawa.

Przypomnijmy zatem, zanim przystąpimy do zasadniczych rozważań, że regionalizm i związane $\mathrm{z}$ nim poczucie wspólnoty na poziomie odmiennym niż narodowy, stanowi jedną z najważniejszych cech kultury Chorwacji. Przez wiele wieków poszczególne regiony budowały swoje modele kulturowe wynikające z uwarunkowań historycznych i społecznych, odzwierciedlające zarazem znaczne zróżnicowanie językowe².

Problematykę tę szczegółowo przeanalizowała Joanna Rapacka w tekście Rola regionalizmu w kulturze chorwackiej, trafnie konstatując, że nowa chorwacka mapa kulturalna, ukazująca polityczne rozbicie kraju i zmiany zasięgu terytorialnego, ukształtowała się na przełomie średniowiecza i czasów nowożytnych. Uczona wskazała na różne wpływy kulturowe kształtujące poszczególne regiony oraz na zakres oddziaływania na nie centrów zewnętrznych, śródziemnomorskich, środkowoeuropejskich i orientalnych ${ }^{3}$. Wynikające $\mathrm{z}$ takich uwarunkowań znaczne zróżnicowanie poszczególnych kultur regionalnych stanowiło przeszkodę $\mathrm{w}$ wypracowaniu modelu ogólnonarodowego, który powstawał w wieku XIX w wyniku szczególnego kompromisu, prowadzącego ostatecznie do odrzucenia wielu wartości istotnych dla poszczególnych regionów.

Ułatwiło to przetrwanie regionalizmowi, który trudności z pełną identyfikacją ze wspólnotą narodową i nie zawsze dostateczną jasność kryteriów odrębności tej wspólnoty kompensował zakorzenieniem w kulturze regionalnej, wyraźnie określonej i w pełni odbieranej jako własna ${ }^{4}$.

\footnotetext{
2 Podstawą komunikacji w różnych regionach były trzy odmienne dialekty - czakawski, kajkawski i sztokawski. Podstawą języka literackiego stał się dialekt sztokawski.

3 J. Rapacka, Godzina Herdera. O Serbach, Chorwatach i idei jugostowiańskiej. Warszawa 1995, s.74-75.

${ }^{4}$ Ibidem, s.84.
} 
Zagadnieniu temu poświęca uwagę również Maciej Falski w pracy Porządkowanie przestrzeni narodowej - przypadek chorwacki, definiując regionalizm jako "tendencję przeciwstawną do głównego nurtu literatury narodowej, podkreślającą autonomię regionów i dążącą do ich afirmacji jako autonomicznych całości w ramach kultury nadrzędnej"5. Tendencja ta, obecna w literaturze chorwackiej przełomu XIX i XX wieku, ponownie daje o sobie znać w ostatnich latach.

Wydarzenia, jakie miały miejsce w latach dziewięćdziesiątych XX wieku, wojna, utworzenie nowego państwa chorwackiego i związane z tym wyraźne dążenia nacjonalistyczne, dobitnie artykułowane przez narodowe centrum, przyczyniły się do powstania fali nowego regionalizmu i zaktywizowania uśpionego potencjału świadomości regionalnej, o którym pisała Rapacka. Stanowi to także element trendu, który ostatnio bardzo się upowszechnił:

renesansu lokalności, małych ojczyzn, etnicznych korzeni, okolic i krajobrazów. Ma on duże znaczenie kulturowe i polityczne, wiąże się z nim nadzieje na odbudowę demokracji i rekonstrukcję tożsamości wyczerpanej konfliktami w sferze dotychczasowych szerszych identyfikacji ${ }^{6}$.

Świadectwem poszukiwania nowych wartości wynikających z przynależności regionalnej jest bez wątpienia tom Slavonski tekst hrvatske književnosti autorstwa Heleny Sablić Tomić i Gorana Rema. Książka ta, bogato ilustrowana i pięknie wydana w 2003 roku nakładem Macierzy Chorwackiej (Matica hrvatska), prezentuje dokonania autorów wywodzących się ze Slawonii, począwszy od początków piśmiennictwa na tych terenach $\mathrm{w}$ wieku XII aż po wiek XX, ze szczególnym uwzględnieniem wydarzeń $\mathrm{z}$ lat dziewięćdziesiątych, które przyniosły temu regionowi szereg dramatycznych doświadczeń i znaczne zniszczenia wojenne. Autorzy wskazują, że to właśnie Slawonia w ostatnich dziesięcioleciach wywierała znaczący wpływ na kulturę ogólnonarodową, jej nowy kształt i przemiany. Mówi się również o specyficznej tożsamości regionalnej czerpiącej inspirację zarazem $\mathrm{z}$ chorwackiego jak i środkowoeuropejskiego kręgu kulturowego ${ }^{7}$. Ze Slawonii pochodzą również autorzy, których językiem ojczystym nie jest chorwacki, ale niemiecki, węgierski, czeski, słowacki czy serbski.

Analizując problem doświadczania przez mieszkańców tego regionu własnej tożsamości w kontekście środkowoeuropejskim, chciałabym przywołać przypadek pisarzy pochodzenia niemieckiego i ich narracji o rodzimej przestrzeni. Na szczególną uwagę zasługuje postać Vilmy Vukelić, autorki pochodzącej z Osijeku i pi-

${ }^{5}$ M. Falski, Porzadkowanie przestrzeni narodowej - przypadek chorwacki. Warszawa 2008, s. 156.

${ }^{6}$ T. Szkudlarek, Miejsce, przemieszczenie, tożsamość. „Magazyn Sztuki” 1998, nr 19, za: E. Rybicka, Geopoetyka (o mieście, przestrzeni i miejscu we wspótczesnych praktykach kulturowych), w: Kulturowa teoria literatury. Główne pojęcia i problemy. Red. M. P. Markowski, R. Nycz. Kraków 2010, s. 482.

${ }^{7}$ H. Sablić-Tomić, G. Rem, Slavonski tekst hrvatske književnosti. Zagreb 2003, s. 11. 
szącej po niemiecku. Jej utwory prozatorskie zostały przetłumaczone na język chorwacki i wydane dopiero wiele lat po jej śmierci w 1956 roku. W powieści autobiograficznej Tragovi prošlosti (Ślady przeszłości, opublikowanej w 1994 roku) Vukelić ożywia ducha miasta na przełomie wieków XIX i XX. Narratorka przywołuje zwykłe, codzienne zwyczaje, przedmioty, modę i obyczajowość lokalnej społeczności. Analizuje nastroje, życie kulturalne, opisuje działalność stowarzyszeń, kreśli portret miasta, którego krytycy nie wahają się nazywać środkowoeuropejskim, co więcej - przynależność do tego kręgu kulturowego nieustannie podkreślają ${ }^{8}$. Strategia ta ma kilka przyczyn, z których najważniejszą wydaje się chęć zachowania ciągłości pamięci. Tanja Radović, autorka tekstu Književnost i nostalgija (Literatura i nostalgia) zwraca uwagę na fakt, że niejednokrotnie w pamięci czy to zbiorowej, czy indywidualnej, pojawiał się opór wobec nostalgii, wynikający z przemilczania zaszłości historycznych (bolesne wspomnienia) oraz spowodowany chęcią uniknięcia niewygodnych pytań. „Nieopłakane” fragmenty historii osobistych czy kolektywnych wywoływały jednak rozmaite frustracje. Tak też stało się w przypadku chorwackim, gdzie ze szczególną intensywnością, właśnie w regionie Slawonii, ożyła chęć odzyskania utraconych sensów.

Przynależność do kręgu środkowoeuropejskiego kryła w sobie bez wątpienia walor nobilitujący, pozwalała odciąć się od sąsiadów - Serbów, postrzeganych jako barbarzyńców nie przynależących do świata cywilizacji europejskiej, przypominała o wydarzeniach historycznych potwierdzających historyczne więzi z Austrią i Węgrami. Pomagała wytyczyć wyraźną granicę między swoimi i obcymi, mieszkańcami Bałkanów, przynależącymi do wzgardzonego Wschodu i europejczykami. Przywrócenie do łask i ożywienie Mitteleuropy pozwoliło zarazem na podróże w czasie. Doskonale ujął to Wojciech Burszta, analizując fenomen Europy Środkowej w tekście Duch Mitteleuropy:

Aby doświadczyć ducha Mitteleuropy, trzeba udać się w wędrówkę pamięci, być po trosze archeologiem pamięci, który mozolnie, warstwa po warstwie, rekonstruuje kolejne pokłady kultur, jakie istniały na permanentnie pogranicznym obszarze Innej Europy ${ }^{9}$.

Jeden ze znaczących przykładów kulturowych podróży w czasie zaczerpnęłam z książki pozornie niezwiązanej z zasadniczym nurtem naszych rozważań - książki kucharskiej zatytułowanej Svapski kulinarij - dodir tradicija u Hrvatskoj (2002) (Szwabskie kulinaria - zetknięcie tradycji w Chorwacji) Nives Rittig Beljak. Wydaje się, że zamieszczone w niej spostrzeżenia, które odnalazłam w rozdziale Kult austriackich ciast, w sposób znaczący ujawniają znaczenie, jakie dla mieszkańców Slawonii,

8 Por. D. Detoni Dujmić, Ljepša polovica književnosti. Zagreb 1998, s. 211-219.

${ }_{9}^{9}$ W. J. Burszta, Duch Mitteleuropy dzisiaj, w: Procesy autoidentyfikacji na obszarze kultur środkowoeuropejskich po roku 1918. Red. J. Goszczyńska. Warszawa 2008, s. 77. 
a w tym szczególnym przypadku miasta Osijeku, ma przynależność do środkowoeuropejskiego kręgu kulturowego. Autorka, przywołując dramatyczne wydarzenia wojenne ostatnich lat, powołuje się właśnie na tę duchową łączność z Europą Środkową, która niesie pocieszenie w ciężkich chwilach:

Podczas wojny, która to wojna naznaczyła w Chorwacji koniec wieku XX, mieszkańcy uparcie bronili tradycji. Cytuję fragment raportu wojennego: „...w Osijeku przywiązuje się wagę do wyrafinowanego wyboru wiedeńsko-pesztansko-praskich słodkości. Miastu, które jest codziennie bombardowane, fizycznie rozbite, którego mieszkańcy zeszli do piwnic, jako swą cywilizacyjną nienaruszoną istotę jako policzek wymierzony prymitywizmowi oferuje swoje szczególne warianty tortu Sachera, tortu somloi, tortu dobosza, czarnego lasu i puchary owocowe..." (Ines Sabolović, „Nedjeljna Dalmacija” 22.9.1991). Doskonałe ciasto zostaje podane na talerzyku symboliki z wieloma przesłaniami począwszy od tego wyrażającego opór wobec barbarzyństwa, po najbardziej oczywiste: nie jesteśmy prowincją - jeśli umieramy, będzie to w stylu Europy Środkowej [tu i dalej tłum. z j. chorwackiego - M. D.] ${ }^{10}$.

Gotowość, a nawet skłonność do wspomnianych przez Bursztę podróży w czasie, właściwa jest autorom o niemieckich korzeniach przywołujących tematykę losu tzw. Szwabów, która stała się źródłem licznych inspiracji fabularnych. Problematyka ta przez wiele lat była skazana na nieistnienie za sprawą politycznych uwarunkowań i niechęci państwa jugosłowiańskiego wobec obciążanych za traumę II wojny światowej niegdysiejszych sąsiadów. Dlatego można spojrzeć na nowe przedsięwzięcia prozatorskie jak na rodzaj zachowań kompensacyjnych, zmierzających do odzyskania utraconej na długo tożsamości, a zarazem przestrzeni, która przez wiele wieków była ich domem.

Szczególnie interesujący jest przypadek tzw. naddunajskich Szwabów (Donauschwaben, zamieszkujących ziemie położone nad Dunajem, określanych także w języku chorwackim mianem Folksdojčeri), który ilustruje krzyżowanie się wpływów różnych kultur na terenach należących do Chorwatów i Serbów (regiony Bačka, Banat, Baranja, Slawonia, Srijem).

Ludność pochodzenia niemieckiego osiedlała się na ziemiach należących do Słowian począwszy od XII wieku, ale ze szczególną intensywnością od wieku XVIII, po upadku imperium osmańskiego. Mniejszość ta miała duży wpływ na rozwój cywilizacyjny Chorwatów ${ }^{11}$ oraz konstrukcję ich tożsamości (środkowo)europejskiej. Wartości, jakie przynieśli ze sobą niemieccy osadnicy, etos pracy oraz poszanowanie dla kultury i sztuki, odmieniły oblicze całego regionu. Dzięki wzajemnym interakcjom wytworzyła się także szczególna tożsamość „Szwabów”,

\footnotetext{
${ }^{10}$ N. Rittig-Beljak, Svapski kulinarij - dodir tradicija u Hrvatskoj. Zagreb 2002, s. 18.

11 Przywołuję tutaj i zamierzam opisać przypadek Chorwatów, ale wpływ cywilizacyjny osadników niemieckich miał również znaczenie w przypadku Serbów czy Bośniaków (osiedlali się w Bośni i Hercegowinie dopiero po 1878 roku).
} 
którzy współtworzyli lokalną kulturę, przyczyniali się do postępu na różnych polach (budownictwo, uprawa ziemi), włączali się w życie chorwackiej społeczności, dbając zarazem o zachowanie własnych tradycji ${ }^{12}$. W miastach rzemieślnicy o niemieckich korzeniach wytyczali modne trendy, zapewniali kontakt z europejskimi nowinkami, kupcy lansowali modne drobiazgi sprowadzane najczęściej z Wiednia.

Wieloletnie relacje uległy gwałtownemu przewartościowaniu po II wojnie światowej, kiedy ludność pochodzenia niemieckiego, która nie zdecydowała się na ucieczkę do Austrii czy Niemiec, poddana została brutalnym represjom. Zastosowano wtedy zasadę zbiorowej odpowiedzialności za niegodziwości wojny i wielu przedstawicieli Szwabów, po tym jak odebrano im całe mienie, umieszczono w obozach koncentracyjnych. Niektórzy z nich osiedlili się potem w Niemczech lub Austrii, rezygnując pod presją Urzędu Bezpieczeństwa z obywatelstwa jugosłowiańskiego, nie zapominając jednak o swojej przeszłości i miejscu pochodzenia. Inni, mimo iż niezbyt liczni (bo chodzi o grupę zaledwie dwutysięczną ${ }^{13}$ ), żyją nadal w Chorwacji i usiłują odzyskać i zrekonstruować swoją tożsamość.

Na pierwsze miejsce spośród autorów wywodzących się z naddunajskich Szwabów bez wątpienia wysuwa się postać Ludwiga Bauera. Jest on autorem kilku już powieści, których głównymi bohaterami uczynił osoby niemieckiego pochodzenia, zaś tematem - ich losy w okresach różnych zawirowań dziejowych. Powieści Bauera bez wątpienia naznaczone są autobiografizmem, ponieważ zarówno dzieje jego rodziny, jak i własne doświadczenia pisarza układają się w jedyną w swym rodzaju opowieść o problemach, jakie zrodziło wieloletnie współtrwanie mieszkańców różnych narodowości na terenach tzw. Podunavlja. Taka więź z osobistymi przeżyciami jest czytelna szczególnie $\mathrm{w}$ przypadku powieści Kratka kronika porodice Weber z 1990 roku oraz wydanej w 2010 roku Zavičaj, zaborav, podejmujących wspólne wątki i opowiadających niejednokrotnie o tych samych postaciach.

Na szczególną wzmiankę zasługuje przypadek pierwszej powieści, której autorowi nie udało się wydać w Chorwacji (pozostającej wówczas w strukturach federacyjnej Jugosławii), ze względu na tematykę, która miała stanowić zagrożenie dla panującej ideologii braterstwa i jedności. Co ciekawe, wydawca znalazł się w Sarajewie i tam właśnie w wydawnictwie "Svijetlost” w 1990 roku ukazała się Kratka kronika porodice Weber. Nie bez znaczenia pozostaje też fakt, że wówczas redaktorem naczelnym w wydawnictwie był Ivan Lovrenović, który napisał pozytywną

$12 \mathrm{O}$ historii przybycia niemieckich osadników zob. V. Geiger, I. Jurković, Što se dogodilo s Folksdojčerima? Zagreb 1993. Autorzy wspominają, że badacze niemieccy uważają Szwabów za "nowe niemieckie plemię" wyraźnie odróżniające się od innych Niemców i reprezentujących inne cechy etniczne.

${ }^{13}$ Istnieje także grupa tzw. krypto-Niemców, osób pochodzenia niemieckiego, którzy deklarują się jako Chorwaci. Por. L. Bauer, Hrvatski Nijemci: zaboravljena manjina ili avangarda europejstva? w: Povijesne zaobilaznice, Nijemci i Austrijanci u Hrvatskoj. Red. N. Rittig-Beljak, L. Marks. Zagreb 2009. 
recenzję prozy Bauera ${ }^{14}$. Za sprawą takich trudności, a potem zawieruchy wojennej, książka nie funkcjonowała w obiegu czytelniczym w Chorwacji, co potwierdzają konstatacje badaczki gatunku powieści historycznej Julijany Matanović. W przedmowie do chorwackiego wydania Krótkiej kroniki... zwróciła uwagę na fakt, że doszło do swego rodzaju zakłócenia recepcji, gdyż powieść zaistniała wśród chorwackich czytelników z wieloletnim opóźnieniem ${ }^{15}$.

Proza Bauera przynależy do nurtu tak zwanej „prozy nowohistorycznej” czy też „prozy o historii” (reprezentowanej przez Nedeljka Fabria, Feđę Šehovicia, Lea Držicia czy Ivana Supeka). Model ten badaczka opisała szczegółowo w książce Krsto i Lucijan (Zagreb 200316) wskazując, że najważniejszą bodaj jego cechą jest podejście do historii, uznanie jej mechanizmów za przyczynę nieszczęść, zła i tragedii, za sprawą których cierpią zwykli, przeciętni ludzie, których nazwiska nic nikomu nie powiedzą. Oni to bowiem, bezradni świadkowie zawieruch dziejowych, mający na poparcie swych relacji jedynie dokumenty i przekazy rodzinne, fotografie i wycinki z gazet, są bohaterami prozy o historii.

Powieść Bauera wpisuje się doskonale $\mathrm{w}$ ten paradygmat, ponieważ Weberowie są zwyczajną rodziną o niemieckich korzeniach, zamieszkującą w Slawonii, w prowincjonalnym miasteczku Gradec. Już we wstępie narrator, porządkując materiał, krótko konstatuje: „Oni nie są ludźmi, o których wspomnienia przechowuje się w muzeach"17. Wspomnienia zachowały się jedynie w kronice rodzinnej, skreślonej ręką Gizeli Weber i dzięki jej staraniom cała zawartość domowego archiwum dociera do narratora.

Z zapisków wyłania się obraz miasteczka Gradec, do którego przybywa antenat rodu Vilmos Weber po wydarzeniach roku 1848, zmuszony do opuszczenia Węgier. Gradec to miejsce fikcyjne, usytuowane gdzieś nad Dunajem, stanowiące literacką reprezentacje slawońskiej przestrzeni, zamieszkiwanej przez przedstawicieli różnych grup etnicznych, w pełni odzwierciedla strukturę społeczną swoich czasów, mentalność mieszkańców Slawonii i relacje pomiędzy przedstawicielami różnych narodowości. Weberowie zmieniają oblicze prowincjonalnego miasteczka, wprowadzają nowe rozwiązania, budują prom, potem most i domy o solidnej konstrukcji, nazwane od ich nazwiska „webericami”.

Prom pop nazwał mostem, mostem cywilizacyjnym, jednym z tych mostów, które w tych czasach „Oświecenia, Postępu i Wolności” coraz mocniej wiążą przebudzone Bałkany z Macierzą Europejską ${ }^{18}$.

${ }^{14} \mathrm{O}$ losach tej powieści Bauera por. G. Beus Richembergh, Povijesni roman kao faktor suvremene povijesti, posłowie do: L. Bauer, Kratka kronika porodice Weber. Zagreb 2001, s. 265-267.

${ }^{15} \mathrm{~J}$. Matanović, posłowie do: L. Bauer, Kratka kronika porodice Weber. Zagreb 2001.

${ }^{16}$ J. Matanović, Krsto i Lucijan: rasprave i eseji o povijesnome romanu. Zagreb 2003, s. 249 [przyp. red.].

17 L. Bauer, Kratka kronika porodice Weber. Zagreb 2007, s. 9.

18 Ibidem, s. 71. 
W ten sposób dokonuje się oswajanie krajobrazu kulturowego, co stanowi formę przystosowania do nowych warunków, nadanie przestrzeni cech swojskości ${ }^{19}$. Działania takie charakterystyczne są dla społeczności postmigracyjnych, które usiłują odtworzyć swoją "przerwaną tożsamość”. Bez wątpienia dynamiczne działania Vilmosa Webera wynikają z chęci zaadaptowania swej tożsamości do realiów Slawonii oraz konieczności oswojenia nowej przestrzeni. Etos pracy i uczciwość odróżniają mieszkańców o niemieckich korzeniach od słowiańskich sąsiadów. Dobitnie zostaje to zaakcentowane w kolejnej powieści Zavičaj zaborav (2010, Strony rodzinne, zapomnienie) opowiadającej o losach młodego Szwaba poszukującego swych korzeni, który dzieciństwo i lata wczesnej młodości spędził w Gradcu pod opieką przybranego ojca, byłego partyzanta:

[...] wobec tych Szwabów brak tolerancji był powszechny, z jednej strony we wszystkim byli lepsi, bardziej staranni, rzecz jasna też skromniejsi, popatrzcie na ich gospodarstwa wiejskie, to jest Europa, a po sąsiedzku królują Bałkany, lenistwo, brud, ciemnota, tyle że ten Bałkańczyk jest tutaj u siebie w domu, a Szwabom zadaje się pytanie, jak i dlaczego tutaj przybyli, proszę cie nie mam złudzeń, znam te rzeczy, oni to Szwaby, ci naddunajscy, przyszli tu przed wszystkimi innymi, przyjechali osuszyć mokradła, ale też prawdą jest, ze nie zintegrowali się z tymi Bałkanami, które tu były. O nie, było na to zbyt mało czasu, do końca I wojny światowej ${ }^{20}$.

Narrator nawiązuje tutaj do obrazu Slawonii ukształtowanego w XIX-wiecznej literaturze chorwackiej oraz literaturze okresu moderny. Problem ten szczegółowo omówił Maciej Falski w cytowanej już wcześniej analizie uporządkowania chorwackiej przestrzeni narodowej. Dla lepszego zilustrowania swojej tezy przywołał szkic Julija Benešicia Raspojasana Slavonija (Rozpasana Slawonia) z 1911 roku, ukazujący stereotypowe postrzeganie regionu jako przestrzeni powszechnej rozwiązłości. „Prawdziwa Slawonia to region zapomniany, pozostawiony rosnącej kolonizacji Węgrów i Niemców" 21 - konstatuje Benešić. Przypomina również, że Slawonia to kraj „wiejskiej idylli i pierwotnych namiętności”, ponieważ jej literackie portrety kreślone przez „piewcę pejzażu slawońskiego” Ivana Kozarca przedstawiają przede wszystkim slawońską wieś22.

Narrator powieści Bauera odwołuje się do tego obrazu, gdy opowiada o chorwackich mieszkańcach miasteczka, ich gwałtownych namiętnościach, ale też prostocie i naiwności. Tym samym przenikają się dwa porządki znaczeń: jeden - można by rzec „słowiański”, wykreowany przez literaturę regionu i drugi - nawiązujący do stereotypu pracowitego Szwaba przywiązanego do swej ziemi i do-

${ }^{19}$ E. Smolarkiewicz, "Przerwana" tożsamość. Odtwarzanie i tworzenie tożsamości w spoteczeństwach postmigracyjnych. Poznań 2010, s. 90.

${ }^{20}$ L. Bauer, Zavičaj, zaborav. Zagreb 2010, s. 227.

${ }^{21}$ M. Falski, op. cit., s. 165.

22 Ibidem, s. 163. 
mu. Atrybuty tych dwóch światów nakładają się na siebie i tworzą nowe kompleksy znaczeń. Co ważne, budulcem tożsamości bohaterów powieści Bauera jest właśnie zakorzenienie $\mathrm{w}$ prowincjonalnym środowisku, łączność z lokalnym otoczeniem. Sytuację, o której mowa, można by doskonale skomentować słowami Mieczysława Dąbrowskiego, analizującego przypadek polskiej literatury kresowej:

Z jednej strony ma się świadomość, że taka oto przestrzeń w jakiś szczególny sposób wytwarza osobowość i charakter ludzi ją zamieszkujących, z drugiej strony mieszkańcy danej przestrzeni czują się $\mathrm{w}$ jakiś specyficzny sposób z nią związani, a piszący wręcz skazani na powielanie pewnego schematu myślenia, zatopienia $\mathrm{w}$ jej szerokości lub swoistej "gęstości" $[\ldots]^{23}$.

Podobnie dzieje się w prozie Bauera rejestrującej nieustannie doświadczenie utraty, wobec którego jednak nie chce ona pozostać bezradną. Przestrzeń stanowi tu model pamięci, przekazując dawne wydarzenia oraz to, jak odnosili się do nich ludzie, którzy tę przestrzeń ukształtowali²4. Gradec zyskał na mentalnej mapie, kreślonej przez Bauera, znaczenie szczególne, stał się miejscem, do którego nieustannie wiedzie wędrówka myśli, kumulującym znaczenia, ale zrazem pozwalającym na odtworzenie utraconych sensów. Nic też dziwnego, że kolejna powieść Karusel, która ukazała się w ubiegłym roku, również dzieje się w Gradcu.

${ }^{23}$ M. Dąbrowski, Kresy w perspektywie krytyki postkolonialnej. „Porównania” 2008, nr 5, s. 19.

${ }^{24}$ S. Kapralski, Pamięć, przestrzeń, tożsamość. Próba refleksji teoretycznej, w: Pamięć, przestrzeń, tożsamość. Red. S. Kapralski. Warszawa 2010, s. 40. 


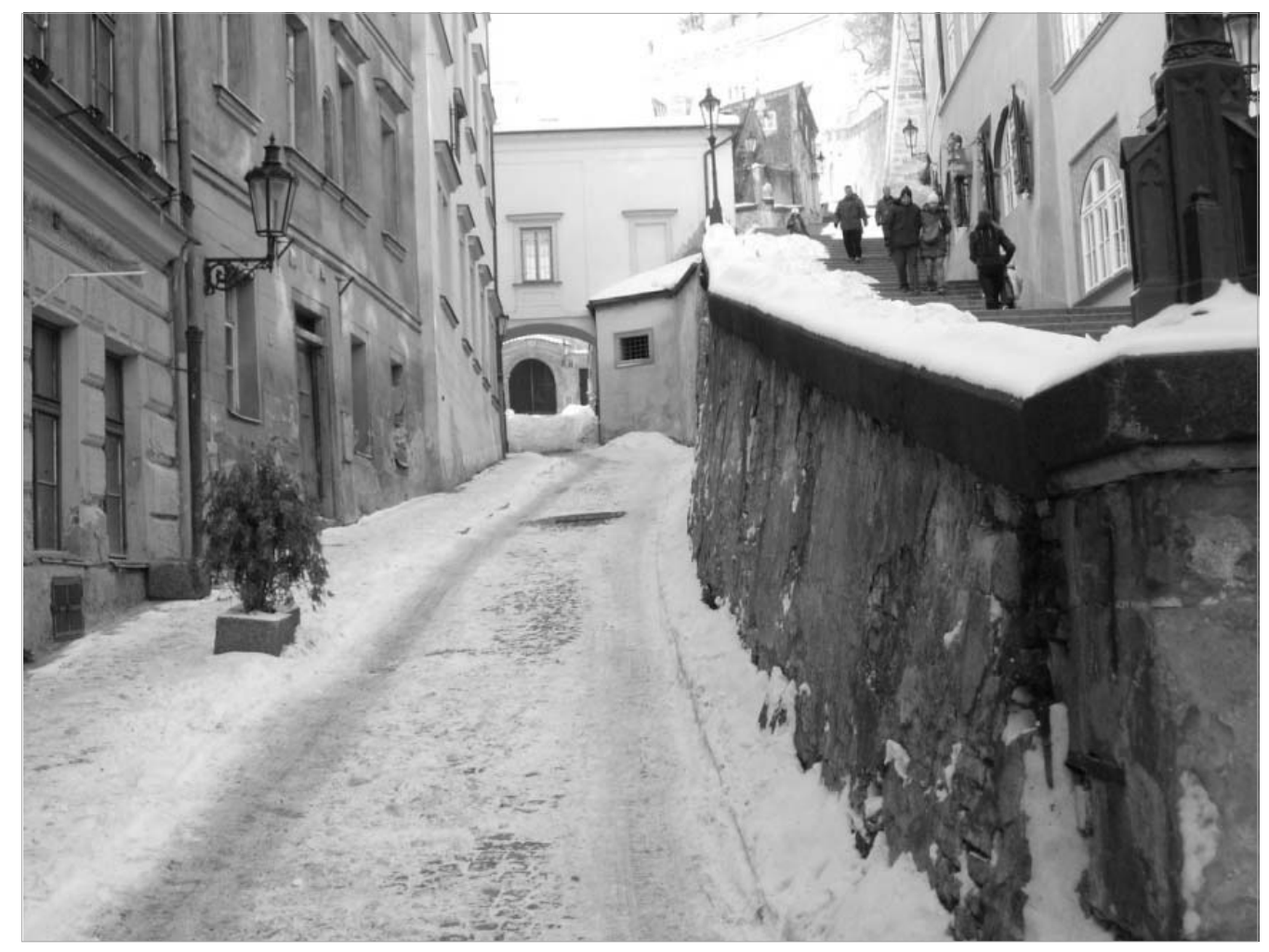

